\title{
A Decolonial Strategy to Reconstruct Student-Management Relationships in a University System
}

\author{
Bunmi Isaiah Omodan \\ School of Social Sciences and Language Education, \\ Bloemfontein Campus, \\ University of the Free State, \\ South Africa
}

DOI: https://doi.org/10.36941/ajis-2021-0034

\section{Abstract}

Despite the contributions of university education to nation-building, the potential of Nigeria's university system to fulfil its responsibilities is frequently obstructed by crises. Among the prominent crises, according to observations and literature, are those linked to student-management dichotomies, which make it practically impossible for universities to actualise their aims. This study is framed by the theory of decoloniality, and aimed to formulate a strategy to enhance the management of crises involving students and universities authorities. Participatory Action Research was adopted as research design. Focus group discussion was used to collect data. Ten participants that acted as co-researchers, from Nigeria, representing university management staff, lecturers, security personnel and student union leaders, both past and present. The participants were selected using the expert sampling technique. Socio-thematic analysis was used to analyse the data. The study revealed that a lack of modern communication, poor dialogue mechanisms, and students' non-involvement in decision-making were major propellers of student-management dichotomies in the university system. The study recommends solutions, among which a mobile/electronic application designed as a strategy to decolonise the old ways of managing students in a university system.

Keywords: Decolonial strategy; Student-management relationships; University system, Crisis, Relationships

\section{Introduction}

All over the world, university education is regarded as the third stage of education, and acknowledged as a universal community of scholars pursuing universal knowledge. In addition to the pursuit of academic excellence, universities in Nigeria were founded to maintain positive norms and other aspects of society's social heritage (Federal Government of Nigeria (FGN), 2013). Despite the contributions of university education to nation building, the potential of the university system to develop countries to fulfil their responsibilities is frequently obstructed by longstanding problems that bedevil the system (Aluede, 2000; 2001; Akinyemi, 2002; Oludayo, Uche, Omonija \& Eche, 2014). This statement has similarities with the conclusions of Ekundayo and Ajayi (2009) and Omodan (2016) that higher education in Nigeria is in travail. The system is riddled with crises of various dimensions and magnitude, whether student or trade union-oriented. The 2013 education reforms in Nigeria centred mainly on planning, curriculum innovation and teacher education, and management mechanisms were 
put in place to rejuvenate the education industry, in order to instil discipline at various universities (FGN, 2013). Jaja (2013) corroborates that the value of efforts of governments, through Ministries of Education at both state and federal levels, to formulate policies, rules and regulations to guide and direct the formation of university systems, is immeasurable. Despite the efforts of governments and other stakeholders to manage university systems, there has been an escalation of student crises (such as abuse of funds, strikes, and lack of support for students by the university management) in almost all Nigerian universities, particularly in public universities (Ajibade, 2013; Omodan, 2016; Orunbon, Salami, Akinyemi, \& Adetunji, 2018).

The effective and efficient management of student crises by universities is not only important, but also necessary for the achievement of educational objectives, which include the inculcation of values, attitudes and skills, coupled with the development of mental and physical abilities towards producing good quality citizens for Nigeria (FGN, 2004; 2013; Jaja, 2013). To achieve these objectives, the existing mechanisms for managing crises in the system must be strengthened. Managing student crises should not rely on crisis control alone; instead, crises must be adequately and well managed to ensure equal distribution of power between students and management authorities. That is, managing student crises should not refer only to the expression of administrative strategies, such as inclusive decision-making, implementing a committee system and dialogue system, and improving students' motivation, among other mechanisms - these solutions should be implemented at the appropriate time. This suggestion is supported by MacNei and Toping (2007), who claim that prevention, preparation and quick response and mobilisation of appropriate resources are part of implementing effective actions to manage contingencies.

Hence, scholars, such as Falua (2004), Mager and Nowak (2012) and Orunbon et al. (2018) recommend that administrative strategies, such as inclusive decision-making, a committee system and using dialogue should rest in the hands of university administrators, so that they can administer a school in a way that fosters productive output, and achieve the goals and objectives of education in general. These recommendations may have been made because student-oriented crises at universities not only appear to have increased, but some of the crises constitute a threat to the well-being of students and entire university communities. Consequently, Aluede (2001) opines that the understudy of emergency has been viewed as a typical wonder in establishments of higher learning since Nigeria's independence, despite indications being around since before independence. Such social crisis has come to attract sociopolitical attention in Nigerian history (Davies, Ekwere, \& Uyanga, 2015; Orunbon et al. 2018).

Increasing the number of universities in Nigeria made tremendous contributions to nation building, but also had other consequences (Adeyemi, 2009), such as student crises and disruption of the academic calendar at some universities (Falua, 2004). Among these events are student crisis at the University of Ibadan in 1971-1972, the University of Lagos in 1978, and the University of Ado Ekiti in 1999. The Federal University of Technology, Akure, experienced wanton destruction of academic and physical property in 2001 (Akinyemi, 2002). In 2002, Lagos State University experienced a crisis after the alleged murder of a union leader and, in 2004, Eboyin State University students went on a rampage to demand social amenities. Similar demands by University of Lagos students in 2016 involved a protest to demand "better life" and a reduction of school fees (Oyediji, 2017). In 2017, students at the University of Ibadan agitated through protests and strikes against hikes in their school fees. Ladoke Akintola University recently experienced undergraduates' distress, because of dichotomies that prompted antisocial vices at the university (Olaniyi, 2017; Oyediji, 2017).

Researchers such as Onwurah (2000), Ekundayo and Alonge (2010) and Omodan (2020) conducted both empirical and non-empirical research on the management of student crises in Nigeria. These scholars conclude that the authorities concerned often use undemocratic measures to manage student crises. They shut down institutions, demand that students who live in university residences vacate the premises, and suspend and dissolve student unions. Government usually takes drastic action by proscribing the students' union associations, rusticating or expelling student leaders and using security forces, like the police and the army, to subdue the tension. This action actually negates the suggestions of scholars, such as Akeusola, Viatonu, and Asikhia (2012), Ajibade (2013), Peter and 
Ebimobowei (2015) and Orunbon et al. (2018), that the use of internal administrative strategies, such as participatory decision-making, a committee system, dialogue, motivation of students, and providing personnel services especially for students, could be productive.

It appears that university experts in Nigeria are not executing the proposed strategies satisfactorily, as confirmed by the perception of Etadon (2013), that the disturbing increase in student unrest and vandalism at universities is, for the most part, caused by heads of establishments. This accusation may not be unconnected with heads' lack of adequate skills and knowledge, which are required to monitor and manage students' agitation due to disagreements. Hence, the aftermath of student crises is usually destructive, and often leads to loss of life, destruction of property and, in particular, interrupts well-planned academic calendars (Davies et al., 2015).

\section{Study Problem}

Over the years, the Nigerian university education system has witnessed a number of unprecedented student-oriented and related crises, which have led to the closure of universities during protests or crises (Akeusola et al., 2012, p. 15; Olaniyi , 2017; Oyediji, 2017). Our observation is that the frequent student protests and crises embarked upon by student unions at universities hinder the actualisation of predetermined goals and objectives. Exemplifying this, it has been traced back to the crises of May 2009, August 2011 and 2014, during the first and second-degree education of one of the researchers at the University of Ado Ekiti, now Ekiti State University, which resulted in unnecessary extension of academic years and the destruction of valuable property belonging to the university. These crises, according to Oyediji (2017) in the Premium Times, also happened at Obafemi Awolowo University, Ladoke Akintola University and University of Lagos.

Therefore, the problem of the study stems from the persistence of students' unrest at Nigerian universities. The crisis scenario is observed to be escalating and, consequently, requires urgent attention. Akeusola et al. (2012, p. 61) state "that students' crisis seems to be on the increase in the universities". It seems that not much has been done to reduce the rate of occurrence of these crises, or to prevent them occurring (Adeyemi, 1999; Davies et al., 2015; Etadon, 2013). Therefore, this study focused on designing a strategy to enhance the management of student-oriented crises at Nigerian universities.

\section{Decoloniality as a Theoretical Framework}

Decoloniality refers not only to the establishment of radical and epistemological movement to achieve liberation and emancipation of formerly colonised people from global coloniality, but is also "synonymous with knowing, decolonial thinking and doing" (Mignolo, 2011, p. 120). However, it is relentless development that arose out of battles against slave exchange, imperialism, politically sanctioned racial segregation, neo-expansionism and underdevelopment that constitutes negative components of Euro-North Americentricism (Ndlovu-Gatsheni, 2015). Decoloniality, according to Quijano (2007, p. 177), "is a response to the relation of direct, political, social and cultural domination established by the Westerners". This means that decoloniality can be seen as sociopolitical and economic practices, opposed to the stake of Western coloniality and modernity (Mignolo, 2011). Decoloniality is opposed to expansionism, imperialism and coloniality, as constituents of the innovative legislative issues of dismantling the politics of dismemberment and exploitation (Gertzel, 2015; Mignolo, 2014).

This theory is relevant to this study because, in this century, students are involved in the fight against perceived oppression, marginalisation and dehumanisation. This trend is evidenced by the conclusion of Aluede, Jimoh, Agwinede, and Omoregie (2015), that students of the $21^{\text {st }}$ century rank their welfare conditions as of little concern to the authorities, and students are easily motivated to form movements that fight against perceived oppression by their institutions. The patterns of student protests and agitations have now metamorphosed, to take the form of criticism of political and national 
issues, especially matters that concern the operation of the university system. The perceived exploitation and dehumanisation of students cannot be underrated, as students experience frequent increments in fees for school, hostel accommodation and other services as systematic exploitation by school management. Likewise, the use of security forces, such as the Mobile Police and soldiers, by school management during protests is regarded as oppressive and anti-humanitarian (Akeusola et al., 2012; Ekundayo \& Alonge, 201).

These seem to be the reasons why students still use forceful means to press home their demands and fight for their rights, especially when they feel marginalised, short changed, dehumanised, colonised and oppressed by the supposed oppressor - university management. This claim is supported by a summary by Gertzel (2015), who explains that decoloniality is an attempt to remake the world in such a way that oppressed, colonised and abused people can recover their ontological thickness, voice, land, history, information, knowledge and power. University authorities, on the other hand, are perceived to be harbouring, still, under the illusion that they are superior to students and, consequently, there is a perception that they have no respect for the rights and freedom of students.

The postcolonial and subsequent military dictatorship in Nigeria seems to have failed to harmonise these two critical stakeholders by disarming students' knowledge and their thinking towards militancy, and bridging the power politics between students and the university authorities. Hence, there is a need for decoloniality, since it seeks to unmask, unveil and reveal coloniality as an underside of modernity. It seeks to disclose rhetoric on progress, equality, fraternity and liberty (Ndlovu-Gatsheni, 2015). By applying the theory of decoloniality to this article, old practices in the system will be uncovered, which may bring about a lasting solution to the problem.

\section{Research Question}

As discussed in the background to the study, the bone of contention is the incessant crises that have eaten deep into the fabric of university education in Nigeria. Therefore, the following research question was raised to pilot the study:

- How can a strategy be designed to enhance crisis management between students and university authorities in Nigeria?

\section{Aims and Objectives of the Study}

The aim of this study was to formulate a strategy that will enhance crisis management between students and authorities of Nigerian universities from a community based participatory research.

\section{Research Objectives}

The study had the following particular objectives:

- To examine the challenges associated with the management of crises between students and university authorities in Nigeria; and

- To investigate possible solutions to challenges related to managing crises between students and university authorities in Nigeria.

\section{Methodology}

The study was located in the transformative paradigm and participatory action research (PAR), which were used as research design for this study, to enable the researcher to examine the nature and the level of internal practices, politics and processes involved in the management of student-oriented crises in Nigeria. PAR as part of transformative paradigm "It is based on the awareness that we live in relation with others and the geophysical environment, implying that we have not only certain rights within this 
relationship, but also a collective responsibility towards the human and non-human world" (Wood, 2020, p. 22). To this end, PAR empowers to formulate a strategy sensitive of the rights of others from a collective approach since it is community-based approach. PAR was found to be relevant because it leads to research-informed change to address lived issues, as the people affected are involved as participants (co-producers of knowledge and action) through iteration planning, action and review (Jowsey \& Desborough, 2016). Therefore, involving student leaders, university authorities, lecturers and security personnel engendered robust analytical information, planning, and the necessary action/change/solutions needed to address the menace of student-management dichotomies. This specific design was appropriate because PAR is seen as an effective means to conduct research "for the purpose of taking action and making change" (MacDonald, 2012, p. 34).

The participants consisted of 10 people: three student leaders, both past and present, three university authority/management staff, two lecturers, two security personnel, that is, a member of the university guard and an officer of Nigerian Security and Civil Defence Corps (NSCDC). The participants were selected using the expert sampling technique, because it enabled the researcher to group experts in the domain of the problem, and to encourage them to share their definitive knowledge, assessment and experience of the problem (Etikan \& Bala, 2017; Kitamaya \& Cohen, 2010). Doing so was essential, as it enabled the researchers to construct better means of generating views from experts about particular events (Gifford, 2015). Focus group discussions were used to collect data from the participants, because, together with PAR, it facilitates defining the problems faced by institutions, and helps find solutions through talking, interrogation, strategic and informed action (Escalada \& Heong, 2014). In the spirit of ensuring that the participants and researchers became collaborate and as a community of researchers, we set various meetings to know each other, to set guidelines for research and we assured them that they are equal partners with everyone in the research teams. As such their views would be valued, respected and will contribute to the formulation of the strategy to enhance crisis management in Nigerian Universities. The study got approval under the ethics committee of University of the Free State, with approval number: UFS-HSD2018/1105. In terms of ethical protocols for this study, as a participatory study cognisant of the need for community involvement, we agree with Wood (2020, p. 92) that "participatory researchers should be committed to living out the values and principles of the research design to collaborate for good, even when it does not directly benefit them". Thus, as researchers we asked them to sign consent forms, assured them that the data would be used for improving crisis management and no harm is anticipated by their involvement in this study. As the study unfolded we continued to monitor ethical protocols to address power imbalances, informed by Wood (2020, p. 92) observation that "continually monitor how the ethical agreement is being implemented". In so doing, we ensured that our research continued as collaborative and community based igniting the transformative nature of PAR.

Socio-thematic Analysis (StA) was used to make sense of the data generated from the participants. This method of data analysis was propounded by Bunmi Isaiah Omodan in 2019. The method propounded by Omodan (2019) represents a combination of thematic analysis as explained by Braun and Clarke (2006), and conversational analysis, as described by Omodan (2019) and Nordquist (2019), which refers to as doing things with words to perform social actions, such as describing, agreeing, questioning, and talking, rather than language that is assumed to be understood when people act out their sociality through conversation. According to Omodan, the use of socio-thematic analysis involves breaking down the transcribed data into relevant units or themes, by becoming familiar with data, generating codes or doing coding, identifying the themes, reviewing the themes, defining and/or naming the themes, and producing reports/analysis using conversationality. That is, the statements under each theme are subjected to a sociality test to enable the analyst to socially interpret the social dependencies and/or independence including social interactions arising from the social differences of the participants (Omodan, 2019). In this study, socio-thematic analysis enable the researcher to inquire into the interplay of power differentials in the participants' compulsory amalgamation in the university society and community the students represent. 


\section{Results and Discussion}

The results of the study will be presented in accordance with the objectives of the study. The first objective relates to the challenges associated with the management of crises between students and university authorities in Nigeria, and will be presented within the following themes: poor communication, lack of dialogue, and students' non-involvement in decision-making. The second objective relates to investigating possible solutions to existing challenges facing managing crises between students and university authorities, and will be presented under the following themes: effective communication, and inclusive engagement. In order to ensure adequate protection and respect for participants' anonymity, the participants were represented as follows: student leaders (SL1, SL2 and SL3), university management (UM1, $\mathrm{UM}_{2}$ and $\mathrm{UM}_{3}$ ), lecturers ( $\mathrm{L}_{1}$ and $\mathrm{L}_{2}$ ), and security personnel ( $\mathrm{SP}_{1}$ and $\mathrm{SP}_{2}$ ).

\subsection{Challenges associated with managing crises involving students and university authorities}

\subsubsection{Communication and Dialogue}

Communication and dialogue is presumed to be one of the mechanisms that could be used in any organisation to manage stakeholders, particularly organisations that have multifaceted kinds of stakeholders, such as a universities. A university community comprises students and teaching and nonteaching staff, including various support staff. For such organisations to succeed, effective communication and a system of dialogue must be adopted to ensure that the views of all stakeholders are recognised and respected, and that the views of managers are communicated to subordinates. Accusations by student organisations in Nigeria, cited by Mbui (2016), indicate that the purposes communication and dialogue are supposed to perform in a university system are either not salient, or do not actually exist in the system. This was confirmed by participant statements in our focus group discussion.

SL3 "One major menace within the university community is lack of adequate information within all segment or departments of the university"

L1 "I will say the mode in which information are being passed to the students through the management is not appropriate enough"

As stated by the participants, information sharing and dissemination is inadequate, not only from the management to students, but also from management to other staff and to departments in the university. We could deduce that the inadequate dissemination of information to students, staff and departments is one of the factors that prevents stakeholders in the university system from mutually cooperating and working harmoniously to achieve the same goal and objectives. The second statement complements the first assertion of a lack of adequate information available for students, staff and departments. The participant claimed that the mode of communication - also referred to as the channel of communication - is another obstacle that hinders the communication flow between management and students at universities. Deducing logically from these statements leads to the conclusion that the sociality of this conversation bothers on unethical superiority of managers, who do not take cognisance of the acceptability of information to the receiver; in other words, they are not particularly concerned about feedback, but expect positive results from every instance of information dissemination. This conclusion is evidenced in the following statement by one of the students:

SL1 "For instance, in a school that is paying school fees, the management can decide in a meeting that, no school fees, no examination. They do this without any form of prior knowledge to the communication with the students, but they expect students to act on the command"

This statement confirms that the mode of communication from management to students is undemocratic - that is, management takes decisions concerning the students without involving students in the process. The students' role is only to receive the information, and they are expected to 
accept it and proceed to the implementation of such decisions. However, socially, respect is reciprocal. We can see here that students believe they are being treated as unimportant stakeholders in the system; and are expected to always respect the power and the people in the position of power. This expectation could lead to conflict, as exemplified in the following statements:

SL2 "Crisis arises because management just decides to take decisions without following the proper communication channels"

$S P 1$ "Most times, the only time management listens to them is when they protest or riot"

UM1 "To a greater extent, people must not shy away from the fact that the age of students that get admission are far young and they do not possess the wisdom, experience and courage that people used to have in the past"

These statements confirm that unpleasant situations, such as protests, misunderstandings, dichotomies and crises, happen as a result of unilateral decision-making and a "I don't care" system of disseminating information to students. Consequently, students decide to go on the rampage, because they know that university management only listens to them when there is student activism in the form of a protest and/or crisis. This finding confirms the findings of Adeyemi (2009), who reports that effective communication, which could help to manage students' agitation and unrest, has not been established in the university system. Bentley (2012) suggests that effective communication, good interpersonal relationships and the dialogue skills of university managers have driven them into circumstantial power politics. However, the last statement above (by Participant UM1) suggests that management believes part of the reason why students are not involved in the process of university management, is because of their youthfulness. This means the participant believes that students who gain admission to university today are not as mature as they used to be and, therefore, the assumption is that management regards them as "too young", and unable to impact the process. The sociality behind this reasoning could be the reason for the usual social disconnect between students and authorities, and indiscriminate social power and power politics in the system, which could lead to crises.

\subsection{Involvement in the decision-making process}

Decision-making and the process involved is one of the actions that is essential for managing organisations. Nwanko (2014) confirms that decision-making is a crisis management strategy, which involves exploring choices among alternative courses of action. Hence, the process of making decisions in a university system should not be undertaken by managers alone, but should involve all stakeholders in the system. However, involving students in the decision-making processes of a university system seems to have received less than its due attention by the university administrators (Sinclair, 2004, p. 106; Adegun \& Arogundade, 2014). This conclusion by the literature is confirmed by the reality, as illustrated by the participants' comments:

SL2 "Management of institution rarely involves us in the process of decision making"

SL1 "The few round table discussion have heard about in the university are as a result of management concluding within themselves and only inviting us to relay their conclusions to us most times might not be palatable to the us, then we take to street to protest"

L2 "Issues affecting the students would have been concluded on and finally decision will be passed to them which most times results in crisis within the institution"

These comments confirm the failure of university authorities to recognise the role of students and their leaders in the operations of the university. The first statement is categorical in stating that management seldom or infrequently involves student leaders in decision-making processes. The second and the third statements buttress the first statement by stating that, despite management's infrequent involvement of students in decision-making, management plays politics by applying a pseudo-democratic style of leadership: They invite students and pretend to involve them, but then only relay to them the 
decisions management has already made, and which they expect students to accept without question, and carry out. This kind of situation reflects social superiority and oppression on the part of university management. Furthermore, this act makes students feel oppressed and marginalised and, in the process, they start considering actions through which their voices can be heard, which often takes the form of causing crises and vandalism. This management behaviour causes students to conclude that their freedom of speech and their right to life is being infringed upon, as demonstrated in the following statements:

$\mathrm{SP}_{2}$ "Information as a result of policies when made by the management without the contribution of student leaders is viewed by them as a means of imposition or infringement on their right as to what affects them. This is evident from experience as to when agitations of students are neglected by the management when brought to their notice"

L2 "Students will always revolt against management in decision-making processes because they believe, that management deprives them their right to freedom of speech and expression"

These comments convey that students believe that university management is imposing unilateral decisions on them, and students interpret it as an infringement of their fundamental human rights. Even when students attempt to communicate their grievances, management fails to take it seriously. In such situations, social inequalities can be observed. The students feel deprived of what they are entitled to; they feel marginalised and systematically colonised. When there is no principle of respect and reciprocity, there is a tendency to experience relationship degeneration between the students and the university authorities. This consequence can be deduced from the following contributions:

\footnotetext{
L2 "the problems arise when management sees students as insubordinates and not as significant contributors to decision-making"

L1 "We cannot shy away from the fact that students are part of the stakeholders within the university community and at every point in time when decisions that affect them are been taken without their input leads to crisis that leads to the total shutdown of the institutions"
}

The evidence is that the actions of university authorities towards students define students as insignificant in relation to decision-making, especially in relation to decisions that concern them, directly or indirectly. These attitudes become conversational when management acknowledges that students are part of the stakeholders, but intentionally exclude them from participating in decisionmaking processes of the university. This confirms that the lack or inadequate participation of the student body in the decision-making of the university predicts, to a large extent, the causes of unrest, mayhem and crisis that is originated by students on campuses. This action not only affects the relationship between the students and university authorities, but also management-staff relationships. Omodan and Dube (2019) found that there is a relationship between the activities of staff unions and the leadership style of university authorities, including the decision-making process of university leaders. The findings of this study is not in consonance with the assumption by the human relations theory of management, which promotes the inclusion of subordinates and all organisational stakeholders in decision-making processes, and suggests a necessity for decoloniality - this will instil a sense of belonging, security and morality, to achieve productivity (Lunenburg \& Ornstein, 2012); thereby making it difficult for students to revolt against the process they were all party to.

\subsection{Possible solutions for challenges facing the management of crises between students and university authorities}

\subsubsection{Effective Communication and Inclusive Engagement}

Communication, belonging, inclusivity and recognition were propounded as some of the assumptions of Human Relations Theory of Management in chapter two, which is, according to Lunenburg and Ornstein (2012, p. 10), essential for increasing subordinates' morale and productivity. This implies that 
inclusive engagement and effective communication in organisations are some of the tools that could enhance mutuality, and help achieve the aims and objectives of the system. The greater the interaction between stakeholders, the greater their tendency to cooperate to achieve one purpose (Odionye, 2014).

Ferdinand (2017) reports that effective communication and inclusive engagement were part of an approach used by the Republic of Ghana to respond to student crises in that country. This approach played out, to some extent, during the focus group discussions with participants in this research. Several conversations confirmed the effectiveness of communication and inclusive engagement in response to student-management dichotomies at universities.

SPI "Issues concerning students should be communicated with the students' leaders and relay to others for them to decide and the management should be willing to compromise at times in other for peace to reign" SL2 "Everyone needs and hope to get a sense of belonging no matter how small which is applicable within all strata of life which does not exclude the University community. Involvement in decision process includes welfarism, security, and increment in certain fees by the University management"

L2 "Effective communication brings about mutual understanding which will commit all persons involved to actualize a set objective. Communication comes with inclusive engagement. Inclusiveness of students is giving out task to individuals in a team. This will strengthen their level of communication"

The first statement reveals that a security officer believed that, if there was adequate and proper dissemination of information between university authorities and student leaders, it would increase the morale and motivation of students to work cooperatively to achieve the objectives of the university there would be less reason to protest or to engage in antisocial activism. The participant recommended, furthermore, that university authorities should learn how to shift ground on issues, and to "let sleeping dogs lie", that is, the authorities must avoid being dictatorial on issues that concern other relevant stakeholders in the university system. Doing so would increase morale and, thereby, increase productivity and avoid crises. In support of the first statement, the second statement recommends that students should be involved in the process of making decisions on sensitive issues, such as security, student welfare, and fee increases. We conclude that these issues, when not addressed, have the potential to distort students' social life, and disturb the peace of the entire environment. From the conversational perspective, the third statement indicates that, when there is inclusivity in the operation of the university system, students and the authorities, and other stakeholders, will see the university goals and objectives as their own project. This will boost morale towards the actualisation of those goals and objectives. Therefore, the university should delegate some power and authority to student leaders, to make them feel recognised and important in relation to the development of the system. These comments provide evidence of this claim.

$\mathrm{SL}_{3}$ "If management communicate with student on a policy, how they are going to implement it and most importantly when they are going to implement it. Hence, if that was the case, there would be no crisis. All the crisis that occur in schools especially university institutions are a result of lack of communication" $S P_{1}$ "If students are told something about a decision before action is taken, they would know what to do. Crisis, and riots would not exist. So it is important to have a team of students that will be able to communicate their views"

These statements confirm that effective communication and inclusive engagement are essential for responding to student-oriented crises at universities in Nigeria. Considering the first statement, information is power. Management activities should not be hidden from students - this includes information on policy formulation and implementation. University authorities should make the role of student leaders important, so that students see themselves as part of the team. By implication, no one will want to destroy what he or she has built with other team members. This means that students and their leaders are unlikely to hold grudges and desire to resist or fight authorities. Furthermore, the last sentence of the second statement, from a conversational point of view, indicates that student leaders alone may not represent the views of all students sufficiently; instead, a team of students will be more 
effective. We believe this approach is important in organisations, because it facilitates teamwork and collaboration. This, in our view, could be regarded as a committee system for and among the stakeholders of the university system.

\subsection{Presentation of the strategy}

\subsubsection{Discussion process to justify the need for a strategy}

In addition to the comments by participants presented above, the participants' conversations during the discussion stage, to formulate a strategy that could respond to the crises between students and the university authorities, were considered as a reason to formulate an electronic application as a strategy. Below are cogent statements by participants that led to unanimous agreement to implement a mobile application.

\footnotetext{
L1: "It doesn't always work like that. More so management should give listening hears to the grievances of students before its escalate to crisis"

"Most times they first give their grievance in form of writing, rumours, side talk to each SP1: other before mobilizing themselves for crisis"

UMA: "Students should be willing to exercise some patience for some decisions to be reversed or taking"

SP2: "Working relationship between the students and management with a constant feedback of activities is important"

SL1: "Constant evaluation of reports by the two parties on a quarterly basis"
}

From the above statements, it is clear that students need a platform where they can communicate their grievances directly to management, without an intermediary. This means management has access to original information from students, and can provide feedback and responses. The second statement indicates that students do not commence with violent action without warning; before they start fighting, they are likely to initiate communication with school authorities. It could be that, in the past, communication did not reach the appropriate authorities, and they could, thus, not take the necessary actions. The statements of the last two conversations provide evidence that students need a channel through which they can, individually, receive direct communication and responses from university authorities. This is necessary because, too often, lack of information, whether about protocols, organisational hierarchy or the university organogram, is perceived to hinder communication upwards and downwards.

SL2: "The university system is organised in a patriarchy management system form which is a top down management system, this time, we need modernised communication system"

SL3: "Information comes from the top and once the information is disseminated, it goes directly to the student head through the student union and from there the rest becomes rumours, one can be told the same statement by management but in ten different versions but when the information is electronically transferred to individual student, there will be less of misconceptions"

UM3: "In order to correct this, the information disseminated from the top, before it gets to the students only to be delivered in many versions, there should be a new communication system in place that all students will have access to"

UM2: "Since all of us are recommending modernised, electronic and new system of communication as the main issue, that means we must consider internet transfer of information? Yes, yes, yes, yes, yes, yes, yes, yes"

L2: "Then formulation of a strategy that will be by creation of a mobile application that will be useful all over the world is inevitable"

From these conversations, it became clear that all the stakeholders value uninterrupted passage of information, either top-down or bottom-up. Moreover, there were agitations, from the participants, for a new version of a communication dissemination system to be implemented; some called it internet transfer of information, others call it modernised, or a new communication system, while some called it electronic transfer of information. To reach agreement was a statement mentioning the need to design of a mobile application, about which there was unanimous agreement. 


\subsection{Unveiling the strategy: "Inter-Response Mobile Application for crisis management"}

The Inter-Response Mobile Application is a system through which students communicate directly with university authorities, and through which university authorities either respond or take relevant actions. The system should be suitable for lodging complaints and for spreading information. Students should be able to get responses to their complaints. For the sake of effectiveness, the system is modelled in two applications, one for students, called the student side application, and the other for the admin, which is for authorised users. The student side application will be open to students at all times, so that they can pass relevant information on to management. This could take the form of case reporting, championing of agitations, expressing grievances, or calling the attention of the university to a particular threat envisaged in the university community. The authorised users' application is the response side. The information technology department will be responsible for this aspect, and will depend on the operational system of the university. This side of the application will have access to all the complaints, comments and information provided by students. The action to be taken depends on the organogram and the departmentalisation of the university. The model is presented in Figure 1.

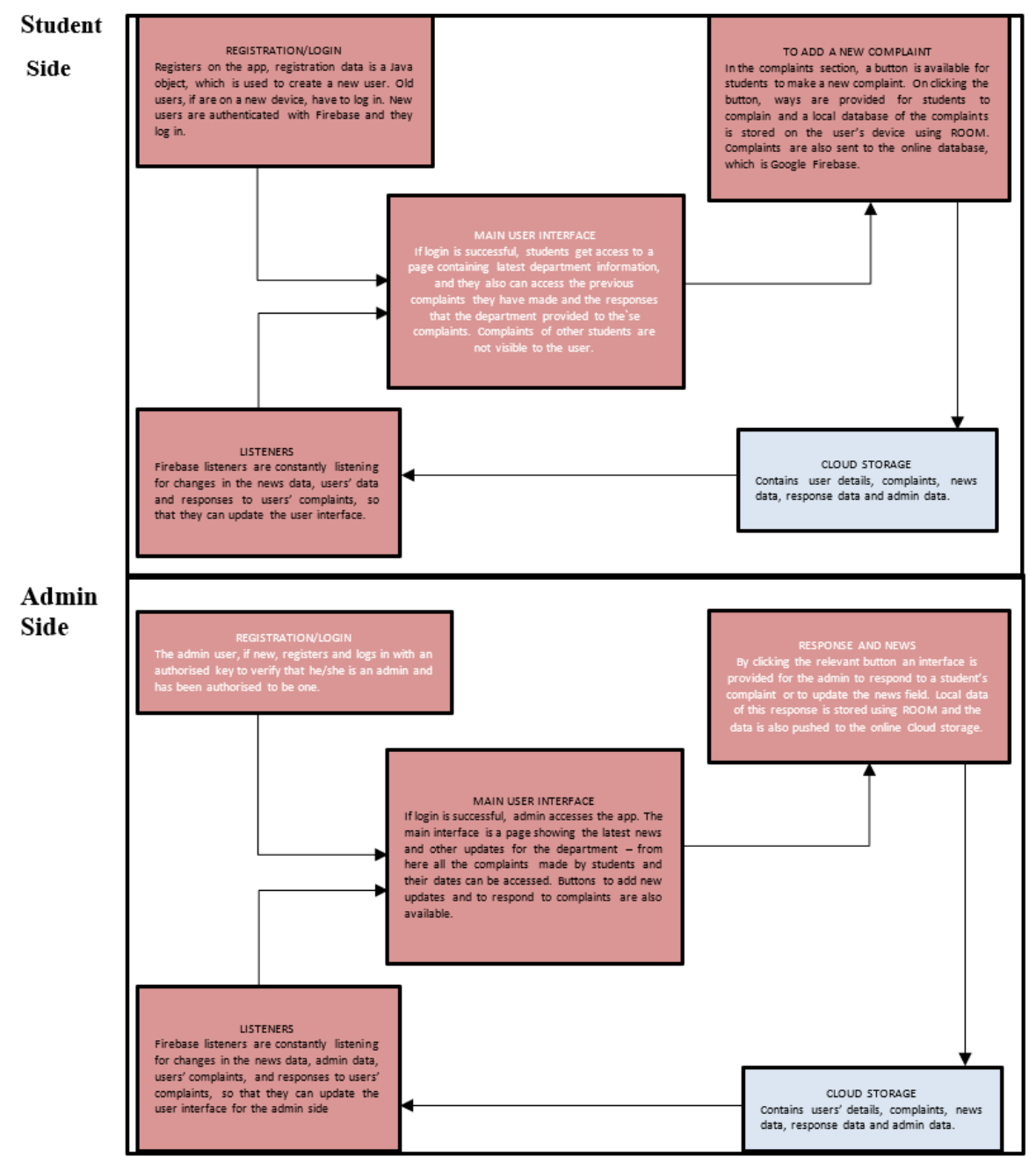

Figure 1: Inter-Response Mobile Application Model 


\section{Conclusion and Implications for Practice}

This strategy presented in Figure 1 is a newly devised means of responding to the dynamic nature of communication in a university system. Therefore, communication that is found to be effective, as in the example of Ghana (Ferdinand, 2017), and as confirmed by the empirical findings of this study, indicates that using mobile applications is suitable for responding to communication deficiencies and ineffectiveness in the process of managing the student-management relationship. The horizontal and vertical - downward and upward - system of communication, as established by the mobile application, could be regarded as a systematic way to implement the principle of inclusivity in managing a university community. Based on the findings of the study, the Inter-Response Mobile Application should be adopted by university managers and leaders in response to the occurrence of crises at universities. This strategy has been confirmed to capture the correlational dependency of lack of communication and dialogue and lack of inclusive decision-making. Adopting the strategy will contribute to peace and relative tranquillity on university campuses. Hence, it is, therefore, recommended that university managers adopt the application to respond and prevent crises occurring in the system. This strategy involves two-way traffic, and information can be exchanged between students and university authorities.

\section{References}

Adegun, O. A., \& Arogundade B. B. (2014). Students' participation in governance and organizational effectiveness in universities in Nigeria. Mediterranean Journal of Social Sciences, 5(9), 2039-2117.

Adeyemi, T. O. (2009). Causes, consequences and control of student's crises in public and private universities in Nigeria. Academic Journals of Educational Research and Review, 4(4), 156-163.

Ajibade, D. (2013). Students' crisis in Nigerian tertiary educational institutions: A review of the causes and management style. Khazar Journal of Humanities and Social Sciences, 16(1), 56-76.

Akeusola O., Viatonu, O., \& Asikhia, O.A. (2012). Perceived causes and control of students' crises in higher institutions in Lagos State, Nigeria. Journal of Education and Practice, 3(10), 60-68.

Akinyemi, B. (2002). Management of students' crisis in higher Institutions in Ekiti State (Unpublished master's thesis). University of Ado-Ekiti.

Aluede, O. O. (2000). An analysis of the attitude of university students towards campus unrest. The Progress of Education, 74, 154-16o.

Aluede, O. O. (2001). Factors Influencing student unrest in tertiary institutions in Edo State of Nigeria. Educational Research Quarterly, 24(3),10-26.

Aluede, O., Jimoh, B., Agwinede, B. O., \& Omoregie, E. O. (2015). Student unrest in Nigerian universities: Looking back and forward. Journal of Social Science, 10(1), 17-22.

Bentley, J. M. (2012). Applying dialogic public relations theory to public relations education. Teaching Journalism and Mass Communication, 2(1), 1-11.

Braun, V. \& Clarke, V. (2006). Using thematic analysis in psychology. Qualitative Research in Psychology, 3(2), 77101.

Davies, K. U., Ekwere, G. E., \& Uyanga, U. U. (2015). Factors influencing students unrest institutions of higher learning and its implications on the academic performance of students in universities of Uyo, Akwa Ibom State, Nigeria. Retrieved from http://research.rs/wp-content/uploads/2016/o6/4-Davies-Ekwere-Uyanga.pdf

Ekundayo, H. T., \& Alonge, H. O. (2010). Managing students' crisis in tertiary institutions in Nigeria. Journal of Research National Development, 8(1): 71-90.

Ekundayo, H. T., \& Ajayi, I. A. (2009). Towards effective management of university education in Nigeria. International NGO Journal, 4(8), 342-347.

Escalada, M., \& Heong, K. L. (2014). Focus group discussion [Online]. Retrieved from https://stirrrd.org/wpcontent/uploads/2019/o3/focus_group_discussion_guide-2.pdf

Etadon, F. I. (2013). Campus conflict involving students and university management in Nigeria: A case study of the University of Ibadan. International Journal of Education Science, 5(3), 333-343.

Etikan, I., \& Bala, K. (2017). Sampling and sampling methods. Biometrics E Biostatistics International Journal, 5(6), $1-3$. 
Falua, B. T. (2004). Management of students crisis in secondary schools in Ado-Ekiti Local Government Area of Ekiti State (Unpublished Master's thesis). University of Ado Ekiti., Nigeria.

Federal Government of Nigeria. (2004). National policy on education. Revised edition. Yaba, Lagos: NERDC Press.

Federal Government of Nigeria. (2013). National policy on education. Revised edition. Yaba, Lagos: NERDC Press.

Ferdinand, E. (2017). Student leaders identify causes and solutions to student unrest in the SHS. Education Ghana. http://educationghana.net/student-leaders-identify-causes-and-solutions-to-student-unrests-in-the-shs/

Gertzel, C. (2015). The politics of independent Kenya. The Australasian Review of African Studies, 36(2), 1-50.

Gifford, B. (2015, April 25). Dr. Oz is no wizard but no quack either. New York Times. https://www.nytimes.com/2015/o4/26/opinion/sunday/dr-oz-is-no-wizard-but-no-quack-either.html

Jaja, J.M. (2013). Higher education in Nigeria: its gain, its burden. Global Journal of Human-Social Sciences Linguistics EEducation, 13(14), 21-29.

Jowsey, T., \& Desborough, J. (2016). Qualitative methodology made easy. University of Auckland Centre for Medical and Health Sciences Education. https://www.fmhs.auckland.ac.nz/assets/fmhs/som/cmhse/docs /Qualitative\%2omethods\%2oresource_Jowsey\%2oDesborough\%2012.08.16\%2ofinal2\%20(2).pdf

Kitamaya, S., \& Cohen, D. (2010). Handbook of cultural psychology. Guilford Press.

Lunenburg, F.C., \& Ornstein, A.C. (2012). Educational administration: Concepts and practices (6th ed). Linda Schreiber-Ganster.

MacDonald, C. (2012). Understanding participatory action research: A qualitative research methodology option. Canadian Journal of Action Research, 13(2), 34-50.

Mager, U., \& Nowak, P. (2012). Effects of student participation in decision making at school. A systematic review and synthesis of empirical research. Educational Research Review, 7(12), 38-61.

Mayor, E. (1933). The human problem of an industrial civilization. New York: Macmillan.

Mbui, V.M. (2016). The role of communication in crisis management in institutions of higher learning in Kenya: a case study of the University of Nairobi (Unpublished master's thesis). University of Nairobi, Kenya.

MacNei, W., \& Toping, K. (2007). Crisis management in schools: evidence-based prevention. Journal of Educational Enquiry, 7(1), 64-94.

Mignolo, W. (2011). The darker side of Western modernity: Global Futures, decolonial options. Durham: Duke University Press.

Mignolo, W. D. (2014). Further thoughts on (de) coloniality. In S. Broeck, \& C. Junker (Eds.). Postcolonialitydecoloniality-black. Chicago: University of Chicago Press.

Ndlovu-Gatsheni, S. J. (2015). Decoloniality as the future of Africa. History Compass, 13(10), 485-496.

Nordquist, R. (2019). Conversation analysis (CA): Glossary of grammatical and rhetorical terms. ThoughtCo [Online]. Retrieved from https://www.thoughtco.com/what-is-conversation-analysis-ca-1689923

Nwanko, J. I. (2014). Management in education: Modern approaches in educational management. Ibadan: Giraffe Books.

Odionye C. M. (2014). Evaluation of crisis management strategies in selected universities in south-east Nigeria (Unpublished master's dissertation). University of Nigeria, Nsukka.

Olaniyi, A., (2017, May 24). Lautech students' protest, blast Aregbesola, Ajimobi over incessant strike. Daily Post. https://dailypost.ng/2017/05/24/lautech-students-protest-blast-aregbesola-ajimobi-incessant-strike/

Oludayo, O. A., Uche, O. O. C., Omonija, D. O., \& Eche, G. A. (2014). Violent protest in private universities in Nigeria: Implications for educational development. European Journal of Social Sciences, 45(4), 359-371.

Omodan, B. I. (2016). Influence of trade unionism on management of tertiary institutions in Ekiti State (Unpublished master's thesis). Ekiti State University, Ado Ekiti, Nigeria.

Omodan, B. I. (2019). Strategy to enhance crisis management between student and university authorities in Nigeria (Unpublished doctoral thesis). University of the Free State, South Africa.

Omodan, B. I. (2020). Combatting the Imperativeness of Modernity in Students' Unrest: The Need to Decolonise the Minds through Ubuntu. International Journal of Higher Education, 9(4), 310319. https://doi.org/10.5430/ijhe.v9n4p310

Omodan, B .I., \& Dube, B. (2019). Bridging the dichotomous gaps between trade unions and management of tertiary institutions in Nigeria. Journal of Social Studies Education Research, 10(1), 285-300.

Onwurah, C. U. (200o). Towards effective management of students' crisis in tertiary institution. Nigerian Journal of Empirical Studies in Psychology and Education, 1(2), 1-10.

Orunbon, N. O., Salami, F. F., Akinyemi, I. A., \& Adetunji, O. K. (2018). Students' crises and their academic performance in Lagos State tertiary institutions, Lagos State, Nigeria. International Journal of Advanced Research in Education \& Technology, 5(1), 7-12. 
Oyediji, O. (2017, May 30). University of Ibadan suspends student union leaders. Premium Times. https://www.premiumtimesng.com/news/more-news/232571-university-of-ibadan-suspends-student-unionleaders.html

Peter, Z. E., \& Ebimobowei, S. T. (2015). Leadership and student unionism, challenges and solutions in the Nigerian tertiary education system (colleges of education, polytechnics and universities). European Scientific Journal, $11(25), 382-392$.

Quijano, A. (2007). Coloniality and modernity/rationality. Cultural Studies, 21(2-3), 168-178.

Sinclair, R. (2004). Participation in practice: making it meaningful, effective and sustainable. Children and Society, 18(2), 106-118.

Wood, L. (2020). Participatory action learning and action research. Theory, practice and process. London: Routledge 